\title{
PATHOPHYSIOLOGICAL MECHANISMS OF ALUMINIUM TOXICITY
}

\author{
Novica Bojanić1, Jelena Milenković2, Dijana Stojanović², Maja Milojković2, \\ Nataša Djindjić1, Marko Gmijović ${ }^{3}$
}

\begin{abstract}
Aluminium forms about $8 \%$ of the earth's crust. It is most commonly found as bauxite ore, which is used for extraction of this metal. Aluminium has a high reactivity and forms compounds such as aluminium oxide, aluminium hydroxide, and potassium aluminium sulfate. Exposure of these compounds to oxidants leads to the formation of a superficial coating of aluminium oxide, which is highly resistant to corrosion and insoluble in water. However, acid rains have allowed the dissolution of these compounds and the entry of aluminium into biological systems. It can enter in human body through water, food, drugs, and inhalation of polluted air.

Once when accumulates in the body aluminium exhibits toxic effects on different organ systems: central nervous, respiratory, skeletal, hematopoietic, reproductive, digestive (liver), and integumentary system. Toxic systemic effects of aluminium are first observed in patients with kidney failure treated with medicines containing aluminium compounds which manifest as: dialysis encephalopathy syndrome, osteomalacia with osteodystrophy and microcytic anaemia.

Aluminium is on the top of a surprisingly short list of neurotoxic inorganic elements and their compounds. It is linked with development of neurodegenerative diseases, including autism, attention deficit disorders, amyotrophic lateral sclerosis, Alzheimer's disease, dementia, Gulf war syndrome, and Parkinsonism. Clinical and experimental studies suggest several possible mechanisms of toxic aluminium action on cells. Those are: increased production of oxidative stress, alteration of membrane function, disruption of intracellular signaling, and alteration or inhibition of enzyme functions.
\end{abstract}

Acta Medica Medianae 2020;59(1):100-109.

Key words: aluminium, toxicity, oxidative stress, neurodegenerative diseases, pathogenesis

1University of Niš, Faculty of Medicine, Niš, Serbia

${ }^{2}$ University of Niš, Faculty of Medicine, Department of

Pathophysiology, Niš, Serbia

${ }^{3}$ Digestive Surgery Clinic, Clinical Center Niš, Niš, Serbia

Contact: Novica Bojanić

11/37 Pariske Komune St., 18000 Niš, Serbia

E-mail: bojanicnovica@gmail.com

\section{Introduction}

Aluminium (Al) is a silvery-white, lightweight, ductile, malleable and non-magnetic metal. It has atomic number 13 and belongs to boron group of the periodic table of the elements. Al forms about $8 \%$ of the earth's crust. Native aluminium is extremely rarely found in nature. It is most commonly found as bauxite ore, which is used for extraction of this metal. Aluminium has a high reactivity and forms compounds such as aluminium oxide, aluminium hydroxide, and potassium aluminium sulfate. Exposure of Al to water, oxygen or other oxidants leads to the formation of a superficial coating of aluminium oxide, which is highly resistant to corrosion. Aluminium oxide is insoluble in water, but it is soluble in mineral acids and strong alkalis. The concentration of dissolved $\mathrm{Al}^{3+}$ is low in surface and subsoil waters, because Al minerals are insoluble at neutral $\mathrm{pH}$. Rain-borne acidification and the use of acidifying fertilizers increase the concentration of soluble $\mathrm{Al}^{3+}$ in soil and waters (1-3). The result of soil pollution is an increase in concentration of aluminium in cultivated plants. This is one of the ways how aluminium may enter in food chain. It was believed that aluminium is harmless to environment, but it is shown that it is toxic to plants and animals (1-3).

Aluminium is widely used in metal alloy production, as a construction material in automotive and aviation industry, electrical industry, as solid fuel rocket propellent, for manufacture of explosives and fireworks. It is also used for the production of cooking utensils and dishes, for food packaging (cans, containers, foils), and as food additives $(4,5)$. 
Mineral compounds of aluminium of natural origin (beonite and zeolite) are used to purify drinking water as coagulants in order to reduce the level of organic matter, color, cloudiness and microorganisms (4-6). Aluminium is also used in pharmacy, medicine, cosmetics and dentistry (antacids, astringents, antiperspirants, dental crowns and dentures) (5).

Aluminium can enter in human body through water, food, drugs, and inhalation of polluted air (57). Aluminium is a non-essential element which is not found in large quantities in human body. The total human body content of aluminium may range from $50-150 \mathrm{mg}$, with an average of about $65 \mathrm{mg}$. Daily intake of aluminium may range from 10-110 $\mathrm{mg}$ (8). It is characterized by low intestinal absorption, slow tissue uptake and rapid urinary excretion. Absorption of $\mathrm{Al}$ in the digestive tract is estimated to be less than $1 \%$. It is influenced by solubility of Al compounds and enhanced with increased gastric acidity, presence of organic acids (ascorbic, citric) and lack of Fe and $\mathrm{Ca}$ in the diet. The accumulation of $\mathrm{Al}$ is reported in patients treated with medicines containing Al compounds (antacids, aluminium in dialysis fluid) in renal failure (8). About half of body content is found in the skeleton, one quarter in the lungs and the rest is in brain, kidneys, liver, spleen and thyroid. Aluminium may pass both blood-brain and placental barrier. It is not recognized that $\mathrm{Al}^{3+}$ has some function in living organisms and it is regarded as biologically inert $(9$, 10). Aluminium when accumulate in human body exhibits toxic effects on different organ systems: central nervous, respiratory, skeletal, hematopoietic, reproductive, digestive (liver), and integumentary system.

\section{system \\ Effects of aluminium on central nervous}

Aluminium is on the top of a surprisingly short list of neurotoxic inorganic elements and their compounds. It is linked with development of neurodegenerative diseases, including autism, attention deficit disorder, amyotrophic lateral sclerosis (ALS), Alzheimer's disease $(A D)$, dementia, Gulf war syndrome and parkinsonism $(7,11-17)$.

Aluminium is accused to develop neurotoxicity through oxidative stress, cell mediated toxicity, apoptosis, inflammatory events in the brain, glutamate toxicity, effects on calcium homeostasis, gene expression, aluminium induced neurofibrillary tangle (NFT) formation and irreversible blockade of ion channels by beta-amyloid $(11,18)$. Neurotoxicity of aluminium salts has been reported in numerous animal studies. Exposition to excessive intake of aluminium causes learning and memory disorders in rats due to deposition of $A \beta$ in the hippocampus and cortex. Al-induced neurophysical and neurobehavioral pathological changes similar to $A D$ were registered in animals $(19,20)$. Chronic exposition of rats to high-dose $\mathrm{AlCl}_{3}$ injections over a prolonged period can reduce locomotor and cognitive functions in rats as well as reduced body weight gain which may be a sign of systemic toxicity (21).
A number of clinical studies have shown that exposure to aluminium in dialysis fluid in patients with kidney failure resulted with encephalopathy. Aluminium induced encephalopathy due to bladder irrigation with $1 \%$ alum in patient with kidney failure is also reported (22). People in Camelford (south west of England) were exposed to the drinking water contaminated with 20 tonnes of aluminium sulphate in July 1988. They had considerable damages of cerebral function, which were not related to anxiety (23). A mild form of encephalopathy was registered in 64 former aluminium dust-exposed foundry workers in Italy. It was characterized by mild intellectual deficit, loss of muscle control, tremor, and spinocerebellar degeneration (24).

Aluminium levels were assessed in $118 \mathrm{pa}-$ tients with neurodegenerative diseases: multiple sclerosis (MS), amyotrophic lateral sclerosis (ALS), Parkinson's disease (PD), and Alzheimer's disease $(A D)$ as well as in 73 healthy subjects. MS was diagnosed in $85.6 \%$ of total neurodegenerative diseases (ND). Al was present in $44.8 \%$ of cases comprehensive of ND and healthy patients. Al level was significantly higher in patients with neurodegenerative diseases than in healthy subjects. Calcium disodium ethylene diaminetetra acetic acid (EDTA) chelation treatment reduced $\mathrm{Al}$ burden in patients with neurodegenerative diseases and ameliorated their clinical conditions (25).

Macrophagic myofasciitis was registered after intramuscular injections of Al-containing vaccines in patients (5). It was characterized by persistence of aluminium hydroxide within macrophages at the site of immunization, muscle lesions, arthromyalgias, chronic fatigue, and cognitive impairment (both visual and verbal memory deficit; including attention deficit) (26).

Aluminium salts (aluminium hydroxide, aluminium phosphate, and aluminium potassium sulfate) have been used in vaccines over eight decades. Even though it has been reported that these salts used as adjuvants can cause severe local reactions (erythema, subcutaneous nodules and contact hypersensitivity) they are still in use, because they enhance antigenicity of some vaccines (as diphtheria and tetanus vaccines) (27).

It was recorded that vaccinated children were exposed more to aluminium (11-26\%) than undervaccinated children. "Power analyses demonstrated that safety studies of aluminium could detect relative risks ranging from 1.1 to 5.8 for a range of adverse event incidence" (28). It has been hypothesized that aluminium hydroxide, which was used as adjuvant in multiple vaccines that soldiers underwent, is associated with Gulf War syndrome (29, 30). The Global Advisory Committee on Vaccine Safety of WHO does not find that there is basis at present to change recommendations for vaccination practices (31).

Though, aluminium neurotoxicity is documented, there is common opinion that healthy adults may tolerate repeated oral exposures to aluminium (up to $3500-7200 \mathrm{mg} /$ day from antacids and buffered aspirin) without any toxic effect. It is explained by low absorption and rapid and primarily urinary excretion of Al compounds. But it is clear 
that even low daily doses of aluminium can cause systemic intoxication in patients with kidney failure, preterm infants and young children (5).

\section{Effects of aluminium on respiratory system}

Aluminium dust has hazardous effect on respiratory system of aluminium production workers. It is shown that they suffer from respiratory symptoms such as cough, wheezing, dyspnea, and chest tightness. Potroom workers who breathe large amounts of aluminium dusts can get wide range of lung diseases: chronic bronchitis, chronic obstructive pulmonary disease, potroom asthma, alveolitis, pneumoconiosis, and even oncological respiratory diseases. All these toxic effects cannot be attributed solely to aluminium. Aluminium potroom workers are exposed not only to alumina dust, but also to particles of fluorides and traces of different elements (vanadium, chromium, nickel), polycyclic aromatic hydrocarbon, mineral dusts (as silica and asbestos), coal tar pitch volatiles, fumes and gases (hydrogen fluoride, carbon oxides, sulfur dioxide, and oxides of nitrogen), extreme heat, and high static magnetic fields $(5,24,32-34)$.

\section{Effects of aluminium on bone and hematopoietic tissue}

Most of the aluminium that accumulates in body is deposited in the bones (8). Aluminium deposits are found also in the hydroxyapatite of the bone matrix in patients with coeliac disease (due to an increased intestinal permeability) and in the case of long-term use of aluminium anti-acid drugs (35, 36).

Patients with kidney failure due to the toxic effect of aluminium in dialysis fluid developed osteomalacia, osteodystrophy and microcytic anemia and dialysis encephalopathy. Aluminium bone disease is characterized by low serum parathyroid hormone (PTH) levels. Removal of aluminium from the dialysate has resulted in disappearance of the bone disease and in an increase in plasma PTH levels (35). The administration of aluminium in rats with chronic renal failure has resulted in reduction of both synthesis and release of PTH (37).

Although very low doses of Al have mitogenic effect in bones of experimental animals, high doses of Al inhibit remodeling of bone by slowing osteoblast and osteoclast activities $(35,36)$. In neonatal rat osteoblast tissue culture $\mathrm{AlCl}_{3}$ has been shown to destroy calcium homeostasis, which activates the $\mathrm{Ca}^{2+} /$ calmodulin-dependent protein kinase II signaling pathway and thus promotes osteoblast apoptosis (38). Al occupies the unmineralized type I collagen, which is freshly laid down at the mineralization front of the bone surface instead of calcium. The result of impaired bone calcification is development of osteomalacia associated with hypercalcemia, and hypercalciuria (25)

Aluminium chronic intoxication causes a microcytic hypochromic anemia in patients with compromised kidney function (39-41). This anemia is not reversible by iron and it is characterized by decreased red cell count as well as hematocrit and hemoglobin concentration. Pathogenesis factors responsible for Al induced anemia are: shortened erythrocyte lifespan due to reduced erythrocyte membrane integrity; inhibition of $\delta$-aminolevulinic acid dehydratase (42), reduced Fe uptake by transferrin due to competitive interaction between iron and aluminium (43).

Downregulation of transferrin receptor expression and impaired intracellular delivery of $\mathrm{Fe}$ from transferrin is also recognized as pathogenesis factor for this type of anemia $(39,40)$.

Similar values of affinity constant of aluminium and iron for the binding of transferrin receptors are recorded in cultured Human erythroleukemic K562 cells. Opposite to previous findings, it is reported that Al modified Fe uptake without affecting the expression of transferrin receptors. It is concluded that $\mathrm{Al}$ induced upregulation of nontransferrin bound iron uptake as an adaptation aimed to enable incorporation of iron which is essential for cellular metabolism (43).

\section{system \\ Effects of aluminium on reproductive}

The decline in male fertility, observed in the twentieth century, is a very current issue in contemporary science. Male fertility has declined by $50 \%$ over several decades of the industrial revolution. It was not known for a long time about harmful effects of aluminium on male fertility (4447). Exposure to Al has been reported to affect testicular development and testosterone synthesis in experimental animals (48-51). Although it was shown that $\mathrm{Al}$ is capable of compromising male fertility by inducing a state of oxidative stress in the testes (48-52), other mechanisms such as inhibition of microtubule assembly could also be involved in Al-induced testicular damage. Aluminium showed negative impact on reproductive abilities of adult bank voles by causing morphologically abnormal development of the gonads and by decreasing the quality and quantity of sperm (53). Intraperitoneal administration of $\mathrm{AlCl}_{3}$ induced dose dependent decrease of testosterone levels in the testes and plasma of mice (48). In male Swiss albino mice treated intraperitoneally with $\mathrm{AlCl}_{3}$ were observed "deformations of the Sertoli cells, epithelial sloughing, tubular atrophy, and abnormal germ cells" (50). In Wistar rats treated with aluminium sulphate in drinking water is recorded significant decrease of sexual accessory glands: seminal vesicles, prostates, bulbourethral glands and of seminiferous tubules (54). Chronic oral exposure to aluminium at low levels is reported to have as negative impact as high levels on reproductive parameters in Wistar rats. These findings are suggesting adverse impact of aluminium on male fertility (55).

Decreased pregnancy rate was observed in untreated females mated with males treated intraperitoneally with 100 or $200 \mathrm{mg} / \mathrm{kg} /$ day of aluminium nitrate for 4 weeks. Treated male mice showed significantly decreased body weight, as well as testicular and epididymal weights. Also, significant decreases in testicular and spermatid counts and epididymal sperm counts were recorded. Sperm moti- 
lity and morphology were unaffected. Histological changes manifested as necrosis of spermatocytes/spermatids in the testes, whereas the tubular diameters were unaffected by aluminium administration (56). A negative impact of aluminium on rabbit sperm cell motility and viability has been shown in vitro (51). Rabbits orally treated with $\mathrm{AlCl}_{3}$ for 16 weeks had significantly decreased libido, ejaculate volume, sperm concentration, total sperm output, sperm motility (\%), total motile sperm per ejaculate, packed sperm volume and total functional sperm fraction. Relative weights of testes and epididymis were also significantly decreased (49). High concentrations of Al in human semen, seminal plasma, spermatozoa, blood, and urine have been linked to poor sperm quality and viability in men (47).

The effects of aluminium on the female reproductive system are not enough elucidated yet. Histopathological changes in the mice ovaries and decreased fertility, after 12 weeks of aluminium chloride administration (dose range 1000-1400 $\mathrm{mg} / \mathrm{kg}$ ) were showed. Both the number of pregnant females and the number of absorbed fetuses were decreased (53). Female mice were exposed by nasal drip during whole pregnancy to Alumina nanoparticles. Aluminium content in hippocampus of newborns was significantly increased. Neurodevelopmental toxicity was registered in the offspring at first month of age as significantly increased anxiety-like behavior with impaired learning and memory performance (57). Subchronic oral exposure to $\mathrm{AlCl}_{3}$ caused the damage of the ovarian structure in rats. Metabolism of $\mathrm{Fe}, \mathrm{Zn}$ and $\mathrm{Cu}$ was disturbed. Activities of $\mathrm{Na}^{+}-\mathrm{K}^{+}$-ATPase, $\mathrm{Mg}^{2+}$-ATPase and $\mathrm{Ca}^{2+}$ ATPase in ovaries decreased, and expression of follicle stimulating hormone (FSH) and luteinizing hormone (LH) receptors were suppressed $(58,59)$. The significant decrease of litter size, modification of sex ratio (increase of female pups number), and significant delay of vaginal opening compared to control group were registered in female Wistar rats exposed to aluminium sulphate by drinking water (60). Oral application of $\mathrm{AlCl}_{3}$ (200 mg daily) during 30 days resulted in a significant decline in uterine and ovarian protein levels and in $3 \beta$ - and $17 \beta-$ hydroxysteroid dehydrogenase activities. Estradiol levels also declined. Hypercholesterolemia and significant accumulation of cholesterol in the ovaries of treated mice as well as accumulation of glycogen in uterus were reported too. Toxic effect in female mice due administration of aluminium chloride has affected steroidogenesis in ovary, and carbohydrate metabolism in uterus. These effects were reversible upon withdrawal of the treatments (61). In adult female Wistar rats treated with aluminium nitrate, the presence of electron-dense material in lysosomes of myometrium and endometrium cells as well as in the cells of the internal theca and granulosa cells was showed by transmission electron microscopy. Also, impaired endoplasmic reticulum, mitochondria and vacuolation were registered. It was concluded that lysosomes of uterus and ovary cells had defense function and extract aluminium and deposit it in an insoluble form (62).

\section{Effects of aluminium on liver}

Aluminium is accumulated in the liver, less than in bones, but the manifestations of Al toxicity in liver have been described. Morphological and morphometric changes highly suggestive of toxic hepatitis were registered in Albino Wistar rats treated with aluminium chloride solved in distilled water intragastrically for 21 days. Architectural derangement was observed as well as degenerative changes at cellular level: nuclear variations such as karyorrhexis and pyknosis (63). In of $\mathrm{AlCl}_{3}$-treated rats a significant rises in plasma levels of AST, ALT, ALP, and $\mathrm{LDH}$ in $\mathrm{AlCl}_{3}$ were recorded as well as a significant reduction in total protein level. A significant level of oxidative stress in liver tissue was also registered (64). High doses of Al induce toxic effects and damage the lysosomes in the liver and the extent of lysosomal damage depended of dose and duration of Al loading (65). Accumulation of bile acids in serum in rats and piglets (66), and increased transferrin excretion in the bile were also found (67). Reduction of some cytochrome P450 isoenzymes, nicotine adenine dinucleotide phosphate (NADPH), cytochrome c reductase, and a 4fold increase in glucuronyltransferase activity were registered in rats treated parenterally with Al. These findings indicate increased conjugating activity (68) and changes in cytochrome P450 isoenzymes may alter metabolism of drugs.

\section{Effects of aluminium on skin}

Although absorbed through the skin, aluminium exposure via intact skin is rather mild, confirming this is an effective barrier (69). Aluminium salts, particularly aluminium chlorohydrate, are used in various antiperspirant cosmetics products, as they block secretion of sweat (70).

Following the dermal application of aluminium chlorohydrate penetration rate was very low (around $0.01 \%$ ) (71). Only insignificant transdermal absorption of Al was shown after application of three different antiperspirant formulations on intact skin. Also, there were low cutaneous quantities of $\mathrm{Al}$ ranging $0.5-1.8 \mu \mathrm{g} / \mathrm{cm}^{2}$. On the other hand, Al uptake after topical antiperspirant application, through the pre-damaged skin (stripped skin) was significantly higher $\left(0.06 \%\right.$ or $\left.11.50 \mu \mathrm{g} / \mathrm{cm}^{2}\right)$ (70). In this respect, there was a discussion of whether the breast cancer was associated with the use of $\mathrm{Al}$ containing antiperspirants, as a form of aluminiumrelated chronic diseases (69). However, no significant link between antiperspirants or deodorants use and increased risk for breast cancer was found. A population based case-control study involving 813 breast cancer patients revealed no significant association of regular antiperspirant use or following hair removal $1 \mathrm{~h}$ after shaving (72).

Intact skin is an effective barrier for Al exposure thus its effects on human keratinocytes are supposed minimal. However, the study of Al nanoparticle interactions with human epidermal keratinocytes showed the particles localization within the cytoplasmic vacuoles of the cells and there was indication of their interactions with cytokine assays 
(73). Detrimental effects of Al were shown on human skin fibroblast cultures and were governed by lipid peroxidation as a pathway of Al cytotoxicity. The experiment showed significant malonodialdehyde (MDA) production after $24 \mathrm{~h}$ incubation with $\mathrm{Al}$ (74). In the perspective, the epidemiological study on internal exposure after antiperspirants use should be performed, and the association with hair removal products or shaving.

\section{Mechanisms of aluminium toxic effects}

Clinical and experimental studies suggest several mechanisms of toxic aluminium action on cells. Those are: increased production of oxidative stress, alteration of membrane function, disruption of intracellular signaling, and alteration or inhibition of enzyme functions. All of them may eventually cause tissue damage.

1. Association of aluminium and increased oxidative stress

Large number of studies demonstrated there is a link between increased Al concentrations and oxidative stress. Generally, there are several mechanisms that produce imbalance between free radical production and antioxidant defense system. Aluminium was shown to take part in disruption of metal ion homeostasis and potential oxidative stress through the reactive oxygen species (ROS) and reactive nitrogen species (RNS) generation $(75,76)$.

Oxidative stress has multiple effects on molecules structure and function, and leads to lipid peroxidation, protein modifications and DNA damage. Aluminium driven oxidative stress was shown to lead to the germ cell apoptosis and decrease in intracellular ATP level (hypoenergosis and motility) (77). Also, its redox state is implicated in a variety of neurological disorders. Another example is Al mediated testicular damage through depletion of antioxidative enzymes protection, and an induction of $\mathrm{NO}$ byproducts and consequent inhibition of steroidogenesis (79). Although Al does not undergo redox change, it may enhance iron driven biological oxidation by formation of $\mathrm{Al}$ superoxide and by catalyzing $\mathrm{H}_{2} \mathrm{O}_{2}$ formation while reducing $\mathrm{Fe}^{3+}$ (78).

By creating a labile iron pool, a redox-active iron, Al interferes with cellular pathways of iron metabolism. This pool has a capacity to promote ROS generation. It is regulated by cytosolic iron regulatory proteins and dependent expression of iron import and storage machineries, or ferritin degradation or synthesis (80).This relationship was proven in animal model study where Al serum levels were found inversely correlated with $\mathrm{Fe}$ serum levels, implying on $\mathrm{Al}$ intoxication intervene in $\mathrm{Fe}$ metabolism (48).

Al can also displace other biological cations, such as calcium, zinc, copper and magnesium from their binding sites. Thus released ions can catalyze hydrogen peroxide transformation to the highly reactive hydroxyl radical, and further initiate lipid peroxidation (81).

Another mechanism of detrimental Al effect is impairment of mitochondrial bioenergetics, also associated with ROS generation (79). Dysfunction of mitochondrial bioenergetics progressively leads to myocardial failure, because energy insufficiency plays a key role in systolic heart failure (82).

Aluminium was also linked to the production of RNS by induction of NO byproducts. Also, increased ROS, through other mechanisms, reduce the amount of bioactive NO by formation of toxic peroxynitrite. Al administration significantly increased NO production and decreased adenosine 3, 5-cyclic monophosphate (CAMP) and testosterone (83).

Several studies demonstrated that Al may cause changes in antioxidants activity, such as superoxide dismutase (SOD), catalase, and glutathione peroxidase/reductase (84). $\mathrm{AlCl}_{3}$ was suggested to inhibit the activity of superoxide dismutase (SOD). It is demonstrated that one month administration of $\mathrm{AlCl}_{3}$ significantly decreased the activities of SOD, suggesting that Al have catalytic activity for ROS production. Reduced SOD and glutathione peroxidase (GPX) activities might be attributed to the elevated level of protein and lipioxidative products (85).

By decreasing the activity of glutathione synthetase, Al might slow the glutathione (GSH) synthesis, one of the most important antioxidants in cells. It is hypothesized that this process occurs through the depletion of ATP. Particularly, Al forms a strong complex with ATP, as it has high affinity toward phosphate ions, and lowers its availability in the cell (79). Another suggested mechanism of decreased GSH is the insufficient supply of NADPH, due to the Al mediated inhibition of NADPH generation. Al inhibits NADP-isocitrate dehydrogenase, the only enzyme supplying NADPH in mitochondria (86). Al, at doses above $120 \mathrm{mg} / \mathrm{kg}$ bw in Wistar rats (orally), produced significant reduction of GSH content and an increase of oxidized/reduced glutathione ratio, in the small intestine mucosa. Also, activities of both GSH synthase and GSSG reductase were significantly reduced. This change in epithelial cells redox state contributed to alteration in $\mathrm{GSH}$ dependent absorptive functions (87).

Al induced oxidative unbalances are associated with lipid peroxidation process. Malondialdehyde (MDA), a lipid peroxidation indicator, is found increased in testis and epididymis after Al exposure (88). Also, lipid peroxidation was found significantly increased in the small intestine when higher Al doses were used (>120 mg/kg) in animal model (89). function

2. Aluminium caused alteration of membrane

The plasma membrane seems to be the target for Al related toxicity, as these trivalent cations readily engaged in interactions with the membrane components thereby affecting associated processes. Al may form electrostatic bonds with oxygen donor ligands or interact with the membrane lipids (79). Also, it may directly alter electrical potential and membrane surface potential (89). Interestingly, binding of $\mathrm{Al}$ to the membrane lipids causes the membrane to become more rigid, which ultimately affects the cell motility and viability (90). Production of ROS and lipid peroxidation of membrane lipids has profound and progressive negative consequences. It hinders membrane fluidity (to become rigid), increase permeability, alter $r$ 
eceptor function, etcetera (79). All these changes further influence intracellular processes such as enzyme inactivation, DNA damage and cell death. Chronic aluminium-in-duced neurotoxicity has been related to lipid per-oxidation of the brain cells that probably arises from altered lipoprotein metabolism (91). disease $(A D)$

3. The channel hypothesis of Alzheimer's

There are controversies about ion channel hypothesis for Alzheimer amyloid peptide neurotoxicity. According to some reports beta-amyloid $(A \beta)$ peptides which accumulate in plaques in the brain in Alzheimer's disease can form ion channels in lipid bilayers. liposomes, neurons, oocyctes, and endothelial cells. These channels are heterogeneous in size, voltage-independent, and poorly selective for ions and they can allow influx of $\left(\mathrm{Ca}^{2+}\right), \mathrm{Na}^{+}, \mathrm{K}^{+}$, $\mathrm{Cs}^{+}, \mathrm{Li}^{+}$, and possibly $\mathrm{Cl}^{-}(18)$. Overload with positive ions may damage and/or kill neurons.

There is no doubt that $A \beta$ is capable to induce transmembrane ion fluctuations in living cells. But in more recent report are presented data which suggest "that $A \beta$ is capable of self-assembling into structures that either form a pore through membranes or generate transient defects in membranes". It is concluded that $\mathrm{Ca}^{2+}$ influx through $A \beta$ induced pores or membrane defects and disruption of $\mathrm{Ca}^{2+}$ homeostasis could contribute to development of Alzheimer's disease. These authors left open the possibility that $A \beta$ activates intrinsic ion channels or ion pumps in cells (92). signaling

4. Aluminium and disruption of intracellular

Several intracellular signaling pathways are reported to be modified by Al ions. Al was found to disturb secondary messenger signaling, including cAMP, $\mathrm{Ca}^{2+}$, and phosphoinositide and inositol-1, 4, 5 -triphosphate $\left(\mathrm{IP}_{3}\right)$, all of which are involved in a variety of processes, ranging from cell growth, differentiation to apoptosis (93).

Aluminium alters cyclic AMP and cyclic GMP levels (less sensitive than AMP). Al has elevated cyclic AMP levels in rat cortex following oral administration for 4 weeks. Supposed mechanism is a Gprotein stimulation of adenylate cyclase as Al may replace the $\mathrm{Mg}^{2+}$ that confers the structure to the triphosphate of GMP (94).
Al is reported as an effective voltage sensitive calcium channel blocker. It blocks Ca entry into the cell and inhibits $\mathrm{Ca}^{2+} / \mathrm{Mg}^{2+}$-ATPase (on endoplasmic reticulum) dependent sequestration of $\mathrm{Ca}^{2+}$ from the cytosol. Al action in this process is complex as it increases the activity of the $\mathrm{Ca}^{2+}$ ATPase, similarly to $\mathrm{Mg}^{2+}$, but also displaces these two molecules and thus disrupts calcium transport (95). When applied extracellularly, Al reduces voltage-activated calcium channel currents in a concentration and $\mathrm{pH}$ dependent manner and irreversibly (96).

Al interference with $\mathrm{IP}_{3}$ and its intracellular depletion is based on $\mathrm{Al}^{3+}$ much higher affinity for the phosphatidylcholine surface than $\mathrm{Ca}^{2+}$ (additionally disturbing $\mathrm{Ca}$ homeostasis) (97).

5. Aluminium caused alteration of enzyme functions Nikotinamide Adenine Dinucleotide Phosphate

Taking into account previously described mechanisms of Al action it can be concluded that there is substantial influence on cellular protein function and metabolism. Its effects on proteins are varied, ranging from alteration in their expression due to the Al binding to deoxyribonucleic acid (DNA) and ribonucleic acid (RNA), to direct inhibition of several enzymes such as hexokinase, phosphatases, phosphodiesterase and phosphooxydase, glucose-6phosphate dehydrogenase and NADP isocitrate dehydrogenase. For example, Al inhibits hexokinase because it changes $\mathrm{Mg}$ ion in Mg-ATPase, a hexokinase substrate (97). Or, by perturbation of intracellular Fe metabolism and Fe-S cluster Al promotes the inhibition of aconitase activity, enzyme involved in metabolism of citrate, in Pseudomonas fluorescens (98).

Al exposure $\left(\mathrm{AlCl}_{3}\right)$ induced significant change of intestinal enzymes, as well as expression of the multidrug resistance-associated protein 2 which was nearly 3-fold increased. Gamma-glutamyltranspeptidase activity was also increased, while glutathione (GSH) synthase and glutathione disulfide (GSSG)reductase were decreased (87).

By changing phosphoinositides metabolism Al causes cytoskeletal rearrangements and abnormalities, which alter cellular motility and viability (78). Already mentioned increased NO production by $\mathrm{Al}$ may react with superoxide or hydrogen peroxide to generate more reactive compounds which cause oxidation of thiol proteins (79). 


\section{References}

1. Becaria A, Campbell A, Bondy SC. Aluminum as a toxicant. Toxicol Ind Health 2002; 18(7):309-20. [CrossRef] [PubMed]

2. Kucharczak E, Moryl A. [Contents of metals in cultivated plants in Zgorzelec-Bogatynia region. Part 1. Lead, cadmium, aluminium]. Ochr Sr Zasobów Nat 2010;42:52-61. Polish

3. Zołotajkin M, Ciba J, Kluczka J, Skwira M, Smoliński A. Exchangeable and bioavailable aluminium in the mountain forest soil of Barania Góra Range (Silesian Beskids, Poland). Water Air Soil Pollut 2011;216(14):571-80. [CrossRef] [PubMed]

4. World Health Organization. Division of operational support in environmental health. Guidelines for drinking-water quality. Vol. 2. Health criteria and other supporting information: addendum, $2^{\text {nd }}$ ed. Geneva: World Health Organization; 1998.

5. Krewski D, Yokel RA, Nieboer E, Borchelt D, Cohen J, Harry J, et al. Human health risk assessment for aluminum, aluminum oxide and aluminum hydroxide. J Toxicol Environ Health B Crit Rev 2007;10(Suppl 1): 1-269. [CrossRef] [PubMed]

6. Federal-Provincial-Territorial Committee on Drinking Water. Guidelines for Canadian Drinking Water Quality Summary Table. February 2017.

7. Rondeau V, Jacqmin-Gadda $H$, Commenges $D$, Helmer C, Dartigues JF. Aluminum and silica in drinking water and the risk of Alzheimer's disease or cognitive decline:findings from 15-year follow-up of the PAQUID cohort. Am J Epidemiol 2009;169(4):489-96. [CrossRef] [PubMed]

8. Długaszek M, Fiejka MA, Graczyk A, Aleksandrowicz JC, Słowikowska M. Effects of various aluminium compounds given orally to mice on Al tissue distribution and tissue concentrations of essential elements. Pharmacol Toxicol 2000;86(3):135-9. [CrossRef] [PubMed]

9. Ganrot PO. Metabolism and possible health effects of aluminum. Environ Health Perspect 1986; 65:363441. [CrossRef] [PubMed]

10. World Health Organization. Guidelines for Drinkingwater Quality. $3^{\text {rd }}$ edition. 2010.

11. Maya S, Prakash T, Madhu KD, Goli D. Multifaceted effects of aluminium in neurodegenerative diseases: A review. Biomed Pharmacother 2016;83:746-54. [CrossRef] [PubMed]

12. Mold M, Umar D, King A, Exley C. Aluminium in brain tissue in autism. J Trace Elem Med Biol 2018;46:7682. [CrossRef] [PubMed]

13. Walton JR. Aluminum in hippocampal neurons from humans with Alzheimer's disease. Neurotoxicology 2006;27(3):385-94. [CrossRef] [PubMed]

14. Bhattacharjee S, Zhao Y, Hill JM, Culicchia F, Kruck $T P$, Percy ME, et al. Selective accumulation of aluminum in cerebral arteries in Alzheimer's disease. ] Inorg Biochem 2013;126:35-7. [CrossRef] [PubMed]

15. Exley C, Vickers T. Elevated brain aluminum and early onset Alzheimer's disease in an individual occupationally exposed to aluminum: a case report. J Med Case Rep 2014;8:41. [CrossRef] [PubMed]

16. Fujiwara T, Morisaki N, Honda $Y$, Sampei M, Tani, $Y$. Chemicals, nutrition, and autism spectrum disorder: a mini-review. Front Neurosci 2016;10:174. [CrossRef] [PubMed]

17. Sealey LA, Sealey LA, Hughes BW, Sriskanda AN, Guest JR, Gibson AD, Johnson-Williams $L$, et al. Environmental factors in the development of autism spectrum disorders. Environ Int 2016;88:288-98.
[CrossRef] [PubMed]

18. Kagan BL, Hirakura $Y$, Azimov R, Azimova R, Lin MC. The channel hypothesis of Alzheimer's disease: current status. Peptides 2002;23(7):1311-5. [CrossRef] [PubMed]

19. Justin Thenmozhi A, Raja TR, Janakiraman U, Manivasagam T. Neuroprotective effect of hesperidin on aluminium chloride induced Alzheimer's disease in wistar rats. Neurochem Res 2015;40(4):767-76. [CrossRef] [PubMed]

20. Justin Thenmozhi A, Dhivyabharathi M, William Raja TR, Manivasagam T, Essa MM. Tannoid principles of Emblica officinalis renovate cognitive deficits and attenuate amyloid pathologies against aluminum chloride induced rat model of Alzheimer's disease. Nutr Neurosci 2016;19(6)269-78. [CrossRef] [PubMed]

21. Abdel-Aal RA, Assi AA, Kostandy BB. Rivastigmine reverses aluminum-induced behavioral changes in rats. Eur J Pharmacol 2011;659(2-3):169-76. [CrossRef] [PubMed]

22. Phelps KR, Naylor $K$, Brien TP, Wilbur $H$, Haqqie SS. Encephalopathy after bladder irrigation with alum: case report and literature review. Am J Med Sci 1999; 318(3):181-5. [CrossRef] [PubMed]

23. Altmann $P$, Cunningham J, Dhanesha $U$, Ballard $M$, Thompson J, Marsh F. Disturbance of cerebral function in people exposed to drinking water contaminated with aluminium sulphate: retrospective study of the Camelford water incident. BMJ 1999;319(7213):80711. [CrossRef] [PubMed]

24. Polizzi S, Pira E, Ferrara M, Bugiani M, Papaleo A, Albera $R$, et al. Neurotoxic effects of aluminium among foundry workers and Alzheimer's disease. Neurotoxicology 2002;23(6):761-74. [CrossRef] [PubMed]

25. Fulgenzi $A$, Vietti $D$, Ferrero ME. Aluminium involvement in neurotoxicity. Biomed Res Int 2014;2014: 758323. [CrossRef] [PubMed]

26. Couette M, Boisse MF, Maison P, Brugieres $P$, Cesaro $P$, Chevalier $X$, et al. Long-term persistence of vaccine-derived aluminum hydroxide is associated with chronic cognitive dysfunction. J Inorg Biochem 2009;103(11):1571-8. [CrossRef] [PubMed]

27. Baylor NW, Egan W, Richman P. Aluminum salts in vaccines - US perspective. Vaccine 2002; 20(Suppl 3):S18-S23. [CrossRef] [PubMed]

28. Glanz JM, Newcomer SR, Daley MF, McClure DL, Baxter RP, Jackson ML, et al. Cumulative and episodic vaccine aluminum exposure in a population-based cohort of young children. Vaccine 2015; 33(48):673644. [CrossRef] [PubMed]

29. Petrik MS, Wong MC, Tabata RC, Garry RF, Shaw CA. Aluminum adjuvant linked to Gulf War illness induces motor neuron death in mice. Neuromolecular Med 2007;9(1):83-100. [CrossRef] [PubMed]

30. Israeli E. Gulf War syndrome as a part of the autoimmune (autoinflammatory) syndrome induced by adjuvant (ASIA). Lupus 2012;21(2):190-4. [CrossRef] [PubMed]

31. World Health Organization. Global Advisory Committee on Vaccine Safety (GACVS). Statement from the Global Advisory Committee on Vaccine Safety on aluminium-containing vaccines. 2008. "cited 2020 May 5" Avaialble from: https://www.who.int/vaccine safety/committee/topics /aluminium/statement 112002/en/

32. Shaaban $\mathrm{LH}$, Zayet $\mathrm{HH}$, Aboufaddan $\mathrm{HH}$, Elghazally SA. Respiratory hazards: clinical and functional 
assessment in aluminum industry workers. Egypt J Chest Dis Tuberc 2016;65(2):537-43. [CrossRef]

33. Kongerud J, Søyseth V. Respiratory disorders in aluminium smelter workers. J Occup Environ Med 2014; 56(5 Suppl):S60-S70. [CrossRef] [PubMed]

34. Donoghue AM, Frisch N, Ison M, Walpole G, Capil R, Curl $C$, et al. Occupational asthma in the aluminum smelters of Australia and New Zealand: 1991-2006. Am J Ind Med 2010;54(3):224-31.

[CrossRef] [PubMed]

35. Chappard D, Bizot P, Mabilleau G, Hubert L. Aluminum and bone: review of new clinical circumstances associated with $\mathrm{Al}\left({ }^{3+}\right)$ deposition in the calcified matrix of bone. Morphologie 2016;100(329):95-105. [CrossRef] [PubMed]

36. Klein GL. Aluminum toxicity to bone: A multisystem effect? Osteoporos Sarcopenia 2019;5(1): 2-5. [CrossRef] [PubMed]

37. Díaz-Corte C, Fernández-Martín JL, Barreto S, Gómez C, Fernández-Coto T, Braga $S$, et al. Effect of aluminium load on parathyroid hormone synthesis. Nephrol Dial Transplant 2001;16(4):742-5. [CrossRef] [PubMed]

38. Cao Z, Liu D, Zhang Q, Sun X, Li Y. Aluminum chloride induces osteoblasts apoptosis via disrupting calcium homeostasis and activating $\mathrm{Ca}\left({ }^{2+}\right) / \mathrm{CaMKII}$ Signal Pathway. Biol Trace Elem Res 2016;169(2):247-53. [CrossRef] [PubMed]

39. Mahieu S, del Carmen Contini M, Gonzalez M, Millen $\mathrm{N}$, Elias MM. Aluminum toxicity. Hematological effects. Toxicol Lett 2000;111(3):235-42.

[CrossRef] [PubMed]

40. Zhang L, Li X, Gu Q, Zhu Y, Zhao H, Li Y, et al. Effects of subchronic aluminum exposure on serum concentrations of iron and iron- associated proteins in rats. Biol Trace Elem Res 2011;141(1-3):246-53. [CrossRef] [PubMed]

41. Jeffery EH, Abreo K, Burgess E, Cannata J, Greger JL. Systemic aluminum toxicity: effects on bone, hematopoietic tissue, and kidney. J Toxicol Environ Health 1996;48(6):649-65. [CrossRef] [PubMed]

42. Schroeder TM, Schroeder TM, Caspers ML. Kinetics of aluminum-induced inhibition of delta-aminolevulinic acid dehydratase in vitro. Biochem Pharmacol 1996; 52(6):927-31. [CrossRef] [PubMed]

43. Pérez G, Pregi N, Vittori D, Di Risio C, Garbossa G, Nesse A. Aluminum exposure affects transferrin-dependent and -independent iron uptake by $\mathrm{K} 562$ cells. Biochim Biophys Acta 2005;1745(1):124-30. [CrossRef] [PubMed]

44. Carlsen E, Carlsen E, Giwercman A, Keiding N, Skakkebaek NE. Evidence for deacreasing quality of semen during past 50 years. BMJ 1992;305(6854): 609-13. [CrossRef] [PubMed]

45. Sengupta $P$, Borges E Jr, Dutta S, Krajewska-Kulak E. Decline in sperm count in European men during the past 50 years. Hum Exp Toxicol 2018;37(3):247-55. [CrossRef] [PubMed]

46. Merzenich $\mathrm{H}$, Zeeb $\mathrm{H}$, Blettner $M$. Decreasing sperm quality: a global problem? BMC Public Health 2010; 10(1):24. [CrossRef] [PubMed]

47. Hovatta O, Venalainen ER, Kuusimaki L, Heikkila J, Hirvi T, Reima I. Aluminum, lead and cadmium concentrations in seminal plasma and spermatozoa, and semen quality in Finnish men. Hum Reprod 1998; 13(1):115-9. [CrossRef] [PubMed]

48. Guo C, Huang C, Chen S, Wang Hsu G. Serum and testicular testosterone and nitric oxide products in aluminum treated mice. Environ Toxicol Pharmacol 2001;10(1-2):53-60. [CrossRef] [PubMed]

49. Yousef MI, El-Morsy AM, Hassan MS. Aluminiuminduced deterioration in reproductive performance and seminal plasma biochemistry of male rabbits: protective role of ascorbic acid. Toxicology 2005;215(1-2): 97-107. [CrossRef] [PubMed]

50. Abdel-Moneim AM. Effects of taurine against histomorphological and ultrastructural changes in the testes of mice exposed to aluminium chloride. Arh Hig Rada Toksikol 2013;64(3):405-14. [CrossRef] [PubMed]

51. Yousef MI, Kamel KI, El-Guendi MI, El-Demerdash FM. An in vitro study on reproductive toxicity of aluminium chloride on rabbit sperm: The protective role of some antioxidants. Toxicology 2007;239(3):213-23. [CrossRef] [PubMed]

52. El-Demerdash FM. Antioxidant effect of vitamin E and selenium on lipid peroxidation, enzyme activities and biochemical parameters in rats exposed to aluminium. J Trace Elem Med Biol 2004;18(1):113-21. [CrossRef] [PubMed]

53. Miska-Schramm A, Kapusta J, Kruczek M. The effect of aluminum exposure on reproductive ability in the bank vole (Myodes glareolus). Biol Trace Elem Res 2017;177(1):97-106. [CrossRef] [PubMed]

54. Trif A, MuselinF, Argherie D, Dumitrescu E, Macinic I. The consequences of chronic exposure to aluminium on some morphological biomarkers of reproductive function (body, genital organs, sexual accessory glands weight, seminiferous tubules diameter) in male rats. Luc Stin Med Vet 2007; 40:652-8.

55. Mouro VGS, Menezes TP, Lima GDA, Domingues RR, Souza ACF, Oliveira JA, et al. How bad is aluminum exposure to reproductive parameters in rats? Biol Trace Elem Res 2018;183(2):314-24. [CrossRef] [PubMed]

56. Llobet JM, Colomina MT, Sirvent JJ, Domingo JL, Corbella J. Reproductive toxicology of aluminum in male mice. Fund Appl Toxicol 1995;25(1):45-51.

[CrossRef] [PubMed]

57. Zhang Q, Ding Y, He K, Li H, Gao F, Moehling TJ, et al. Exposure to alumina nanoparticles in female mice during pregnancy induces neurodevelopmental toxicity in the offspring. Front Pharmacol 2018;9:253. [CrossRef] [PubMed]

58. Mohammed A, Mayyas I, Elbetieha A, Shoter A, Khamas W, Elnasser Z. Toxicity evaluation of aluminium chloride on adult female mice. J Anim Vet Adv 2008;7(5):552-6.

59. Fu Y, Jia FB, Wang J, Song M, Liu SM, Li YF, et al. Effects of sub-chronic aluminum chloride exposure on rat ovaries. Life Sci 2014;100(1):61-6.

[CrossRef] [PubMed]

60. Trif A, Dumitrescu E, Muselin F. Aluminium sulphate impact on some markers of female reproductive system performances (litter size, sex ratio) and of physical development (vaginal opening) in rats. Bull USAMV Vet Med 2008; 65(2):97-106.

61. Chinoy NJ, Patel TN. Effects of sodium fluoride and aluminium chloride on ovary and uterus of mice and their reversal by some antidotes. Fluoride 2001;34 (1):9-20.

62. Marwa M, Adrian F, Nedra B, Samira M, Horea M, Walid-Habib $T$, et al. The role of lysosomes in the phenomenon of concentration of aluminum and indium in the female reproductive system. An ultrastructural study. J Trace Elem Med Biol 2017;44:5964. [CrossRef] [PubMed]

63. Agarwal DR, Gupta SB. An alarming hazard in the community using aluminium in day to day life on the basis of toxic effects on the liver of Albino rats by ingestion of aluminium. Nat J Comm Med 2010; 1(2):82-4.

64. Cheraghi E, Roshanaei K. The protective effect of curcumin against aluminum chloride induced oxidative 
stress and hepatotoxicity in rats. Pharm Biomed Res 2019;5(1):6-13. [CrossRef]

65. Lewandowska-Szumiel $M$, Komender J. Aluminium release as a new factor in the estimation of alumina bioceramic implants. Clin Mater 1990;5(2-4):167-75. [CrossRef] [PubMed]

66. Klein $G L$, Sedman AB, Heyman MB, Marathe G, Battifora HA, Worrall JL. Hepatic abnormalities associated with aluminum loading in piglets. JPEN - J Parenter Enter Nutr 1987;11(3):293-7. [CrossRef] [PubMed]

67. Klein GL, Goldblum RM, Moslen MT, Pyron DL, Mann $\mathrm{PA}$, Lee TC, et al. Increased biliary transferrin excretion following parenteral aluminium administration to rats. Pharmacol Toxicol 1993;72(6):373-6.

[CrossRef] [PubMed]

68. Bidlack WR, Bidlack WR, Brown RC, Meskin MS, Lee TC, Klein GL. Effect of aluminum on the hepatic mixed function oxidase and drug metabolism. Drug Nutr Interact 1987;5(1):33-42. [PubMed]

69. Klotz K, Weistenhöfer W, Neff F, Hartwig A, van Thriel $C$, Drexler $H$. The health effects of aluminum exposure. Dtsch Arztebl Int 2017;114(39):653-9. [CrossRef] [PubMed]

70. Pineau A, Guillard O, Favreau F, Marrauld A, Fauconneau B. In vitro study of percutaneous absorption of aluminum from antiperspirants through human skin in the Franz diffusion cell. J Inorg Biochem 2012;110:21-6. [CrossRef] [PubMed]

71. Flarend R, Bin T, Elmore D, Hem SL. A preliminary study of the dermal absorption of aluminium from antiperspirants using aluminium-26. Food Chem Toxicol 2001;39(2):163-8. [CrossRef] [PubMed]

72. Mirick DK, Davis S, Thomas DB. Antiperspirant use and the risk of breast cancer. J Natl Cancer Inst 2002; 94(20):1578-80. [CrossRef] [PubMed]

73. Monteiro-Riviere NA, Oldenburg SJ, Inman AO. Interactions of aluminum nanoparticles with human epidermal keratinocytes. J Appl Toxicol 2010;30(3):276-85. [CrossRef] [PubMed]

74. Anane R, Creppy EE. Lipid peroxidation as pathway of aluminium cytotoxicity in human skin fibroblast cultures: Prevention by superoxide dismutase+catalase and vitamins E and C. Hum Exp Toxicol 2001;20(9): 477-81. [CrossRef] [PubMed]

75. Flora SJ, Mittal M, Mehta A. Heavy metal induced oxidative stress $\&$ its possible reversal by chelation therapy. Indian J Med Res 2008;128(4):501-23. [PubMed]

76. Jomova K, Valko M. Advances in metal-induced oxidative stress and human disease. Toxicology 2011; 283(2-3):65-87. [CrossRef] [PubMed]

77. Turner TT, Lysiak JJ. Oxidative stress: a common factor in testicular dysfunction. J Androl 2008;29(5): 488-98. [CrossRef] [PubMed]

78. Mahdi AA, Tripathi S, Neerja J, Hasan M. Aluminium mediated oxidative stress: possible relationship to cognitive impairment of Alzheimer's type. Ann Neurosci 2006;13(1):19-24. [CrossRef]

79. Pandey G, Jain GC. A review on toxic effects of aluminium exposure on male reproductive system and probable mechanisms of toxicity. International Journal of Toxicology and Applied Pharmacology 2013;3(3): 48-57.

80. Kakhlon O, Cabantchik ZI. The labile iron pool: characterization, measurement, and participation in cellular processes (1). Free Radic Biol Med 2002; 33 (8):1037-46. [CrossRef] [PubMed]

81. Yokel RA. Brain uptake, retention, and efflux of aluminum and manganese. Environ Health Perspect 2002; 110(Suppl 5):699-704. [CrossRef] [PubMed]
82. Sheeran FL, Sheeran FL, Pepe S. Mitochondrial bioenergetics and dysfunction in failing heart. Adv Exp Med Biol 2017;982:65-80. [CrossRef] [PubMed]

83. Guo CH, Lin CY, Yeh MS, Hsu GS. Aluminum-induced suppression of testosterone through nitric oxide production in male mice, Environ Toxicol Pharmacol 2005; 19(1):33-40. [CrossRef] [PubMed]

84. Moumen R, Ait-Oukhatar N, Bureau F, Fleury C, Bouglé $D$, Arhan $P$, et al. Aluminum increases xanthine oxidase activity and disturbs antioxidant status in the rat. J Trace Elem Med Biol 2001;15(2-3):89-93. [CrossRef] [PubMed]

85. El-Gendy AM. Amelioration of Aluminium - intake oxidative stress by some antioxidants in male albino rats. Egypt J Hosp Med 2011; 45:536-46.

86. Murakami K, Yoshino M. Aluminum decreases the glutathione regeneration by the inhibition of NADPisocitrate dehydrogenase in mitochondria. J Cell Biochem 2004;93(6):1267-71. [CrossRef] [PubMed]

87. Orihuela D, Meichtry V, Pregi N, Pizarro M. Short-term oral exposure to aluminium decreases glutathione intestinal levels and changes enzyme activities involved in its metabolism. J Inorg Biochem 2005; 99(9):18718. [CrossRefCrossRef] [PubMed]

88. Hala AH, Khattab ZA, Abdallah G, Kamel M. Grape seed extract alleviate reproductive toxicity caused by aluminium chloride in male rats. J Am Sci 2010;6 (12):352-61.

89. Ahn S, Matsumoto $H$. The role of the plasma membrane in the response of plant roots to aluminum toxicity. Plant Signal Behav 2006;1(2):37-45. [CrossRef] [PubMed]

90. Deleers M, Servais JP, Wülfert E. Neurotoxic cations induce membrane rigidification and membrane fusion at micromolar concentrations. Biochim Biophys Acta 1986;855(2):271-6. [CrossRef] [PubMed]

91. Belaïd-Nouira Y, Bakhta H, Bouaziz M, Flehi-Slim I, Haouas Z, Ben Cheikh H. Study of lipid profile and parieto-temporal lipid peroxidation in $\mathrm{AlCl}_{3}$ mediated neurotoxicity. Modulatory effect of fenugreek seeds. Lipids Health Dis 2012;11:16. [CrossRef] [PubMed]

92. Capone R, Quiroz FG, Prangkio P, Saluja I, Sauer AM, Bautista MR, et al. Amyloid- $\beta$-induced ion flux in artificial lipid bilayers and neuronal cells: resolving a controversy. Neurotox Res 2009;16(1):1-13. [CrossRef] [PubMed]

93. Haug A, Haug A, Shi B, Vitorello V. Aluminum interaction with phosphoinositide-associated signal transduction. Arch Toxicol 1994;68(1):1-7. [CrossRef] [PubMed]

94. Johnson GV, Jope RS. Aluminum alters cyclic AMP and cyclic GMP levels but not presynaptic cholinergic markers in rat brain in vivo. Brain Res 1987; 403(1): 1-6. [CrossRef] [PubMed]

95. Mundy WR, Kodavanti PR, Dulchinos VF, Tilson HA. Aluminum alters calcium transport in plasma membrane and endoplasmic reticulum from rat brain. ] Biochem Toxicol 1994;9(1):17-23. [CrossRef] [PubMed]

96. Platt B, Büsselberg D. Actions of aluminum on voltage-activated calcium channel currents. Cell Mol Neurobiol 1994;14(6):819-29. [CrossRef] [PubMed]

97. Ochmanski W, Barabasz W. [Aluminium-occurrence and toxicity for organisms]. Przegl Lek 2000;57(11): 665-8. Polish [CrossRef] [PubMed]

98. Middaugh J, Middaugh J, Hamel R, Jean-Baptiste G, Beriault R, Chenier D, Appanna VD. Aluminum triggers decreased aconitase activity via Fe-S cluster disruption and the overexpression of isocitrate dehydrogenase and isocitrate lyase: a metabolic network mediating cellular survival. J Biol Chem 2005;280(5):3159-65. [CrossRef] [PubMed] 


\title{
PATOFIZIOLOŠKI MEHANIZMI ALUMINIJUMSKE TOKSIČNOSTI
}

\author{
Novica Bojanić ${ }^{1}$, Jelena Milenković ${ }^{2}$, Dijana Stojanović ${ }^{2}$, Maja Milojković2 \\ Nataša Đinđić1 ${ }^{1}$ Marko Gmijović ${ }^{3}$
}

\author{
${ }^{1}$ Univerzitet u Nišu, Medicinski fakultet, Niš, Srbija \\ ${ }^{2}$ Univerzitet u Nišu, Medicinski fakultet, Katedra za patološku fiziologiju, Niš, Srbija \\ ${ }^{3}$ Klinika za digestivnu hirurgiju, Klinički centar Niš, Niš, Srbija
}

Kontakt: Novica Bojanić

Pariske Komune 11/37, 18000 Niš, Srbija

E-mail: bojanicnovica@gmail.com

Aluminijum čini oko $8 \%$ minerala zemljine kore. Najčešće se nalazi u obliku boksita rude koja se koristi za dobijanje tog metala. Aluminijum je visoko reaktivan i formira jedinjenja kao što su aluminijum-oksid, aluminijum-hidroksid i natrijum-aluminijum-sulfat. U kontaktu sa oksidansima, ta jedinjenja stvaraju površni pasivizirajući sloj aluminijum-oksida, koji sprečava koroziju i čini ga nerastvorljivim u vodi. Međutim, kisele kiše omogućavaju rastvaranje tih jedinjenja i ulazak aluminijuma u biološke sisteme. Aluminijum može ući u ljudski organizam preko vode, hrane, lekova i udisanjem zagađenog vazduha. Nakon što se akumulira u telu, on ispoljava toksične efekte na: centralni nervni, respiratorni, hematopoetski, reproduktivni, digestivni (jetru) i koštani sistem. Toksični sistemski efekti aluminijuma najpre su uočeni kod bolesnika sa bubrežnom insuficijencijom, lečenih lekovima koji sadrže aluminijumska jedinjenja (dijalizna encefalopatija, osteomalacija sa osteodistrofijom i mikrocitna anemija).

Aluminijum je u vrhu kratke liste neurotoksičkih neorganskih elemenata i njihovih jedinjenja. Povezuje se sa razvojem neurodegenerativnih bolesti, uključujući autizam, poremećaje pažnje, amiotrofičnu lateralnu sklerozu, Alchajmerovu bolest, demenciju, sindrom Zalivskog rata i parkinsonizam. Kliničke i eksperimentalne studije ukazale su na više mogućih mehanizama kojima aluminijum toksično utiče na ćelije. Tu spadaju: povećana produkcija oksidativnog stresa, promena funkcije membrana, poremećaj intracelularne signalizacije i promena ili inhibicija funkcije enzima.

Acta Medica Medianae 2020;59(1):100-109.

Ključne reči: aluminijum, toksičnost, oksidativni stres, neurodegenerativne bolesti, patogeneza 